\title{
THE INFORMATION AUDIT: PRINCIPLES AND
}

\section{GUIDELINES}

by

\section{Hannerí Botha}

In fulfilment of the requirements for the degree

$$
\text { M.BIBL. }
$$

in the Faculty of Humanities

University of Pretoria, PRETORIA

October 2000 


\section{TABLE OF CONTENTS}

LIST OF FIGURES, TABLES AND ADDENDUMS

1. Introduction

2. Problem and context

2.1 What gives rise to the problem?

2.2 Statement of problem/Purpose of the study

2.3 Sub-problems

2.4 Necessity for finding a solution to the problem

2.5 Defining the boundaries of the study terrain

2.6 Definitions of key terms

2.6.1 Information audit

2.6.2 Financial audit

2.6.3 Information mapping

2.6.4 Communication audit

2.7 Assumptions made

2.8 The contribution of this study to the solution of the problem

3. An overview of the current state of research on the topic

3.1 Nature of theory and research

3.2 Main findings from the literature

3.3 Conclusions/proposals from the literature

3.4 Motivation from the literature for the continuation of the research

$\begin{array}{lll}\text { 4. Methodology } & 7\end{array}$

$\begin{array}{lll}\text { 5. Structuring of chapters } & 7\end{array}$

CHAPTER 2: THE FINANCIAL AUDIT $\quad 8$

$\begin{array}{lr}\text { Chapter 2: Overview } & 8\end{array}$

$\begin{array}{lr}\text { 1. Introduction } & 8\end{array}$

2. Definitions of key terms $\quad 8$

3. Auditing: A historical overview 8

3.1 The history and origins of auditing $\quad 8$

4. The nature and objectives of an audit 9

4.1 The nature of auditing 9

$\begin{array}{ll}\text { 4.1.1 Independent/external/financial auditing } & 10\end{array}$

$\begin{array}{lll}4.1 .2 & \text { Internal auditing } & 10\end{array}$

4.1.3 Governmental auditing 11

4.1.4 Operational auditing 11

4.1.5 Management auditing 13

4.1.6 Comprehensive auditing 13

$\begin{array}{lll}\text { 4.1.7 Other audits } & 13\end{array}$ 
4.2 The objectives of an audit 13

4.2.1 Major objectives of an audit 13

4.2.2 Secondary objectives and advantages of an audit 13

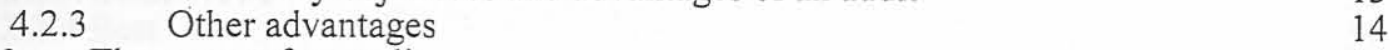

$\begin{array}{lll}4.3 \text { The scope of an audit } & 14\end{array}$

4.4 Classes of audits 14

5. The auditing process 15

5.1 Procedures and activities that make up the auditing process 16

$\begin{array}{lll}5.1 .1 & \text { Pre-engagement activities } & 16\end{array}$

$\begin{array}{lll}5.1 .2 & \text { Planning } & 16\end{array}$

$\begin{array}{ll}\text { 5.1.3 Compliance and substantive procedures } & 17\end{array}$

$\begin{array}{ll}\text { 5.1.4 Evaluating, concluding and reporting } & 17\end{array}$

$\begin{array}{lll}5.2 & \text { Different approaches to the auditing process } & 17\end{array}$

$\begin{array}{lll}5.3 & \text { Common auditing activities } & 17\end{array}$

6. The auditing profession and the professional auditor 18

6.1 Qualifications 18

6.2 The auditor's responsibilities 18

6.2.1 Reports his opinion 18

$\begin{array}{ll}\text { 6.2.2 Conducts the audit with due professional care and competence } & 18\end{array}$

6.2.3 Maintains an independent mental attitude 18

$\begin{array}{ll}\text { 6.2.4 Reports on material irregularities } & 18\end{array}$

6.2.5 Detects and reports illegal acts, other irregularities and errors 19

6.2.6 Registers with the PAAB (Public Accountants' and Auditors' Board) 19

$\begin{array}{ll}\text { 6.2.7 Adheres to code of conduct } & 19\end{array}$

7. Auditing and accounting standards 19

$\begin{array}{ll}7.1 \quad \text { Auditing standards } & 19\end{array}$

$\begin{array}{ll}7.2 & \text { Accounting standards } \\ 7.3 & 20\end{array}$

$\begin{array}{ll}7.3 \text { Quality control } & 20\end{array}$

$\begin{array}{ll}\text { 7.3.1 The South African situation } & 20\end{array}$

$\begin{array}{ll}\text { 7.3.2 The international scene } & 22\end{array}$

$\begin{array}{lll}\text { 8. Conclusion } & 22\end{array}$

CHAPTER 3: THE COMMUNICATION AUDIT, THE INFORMATION SYSTEMS AUDIT, INFORMATION MAPPING, THE INTELLIGENCE AUDIT AND THE KNOWLEDGE AUDIT

Chapter 3: Overview 23

1. Introduction 23

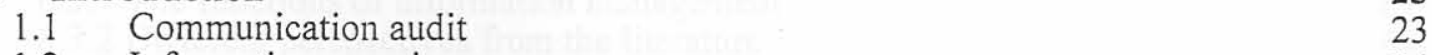

1.2 Information mapping 24

$\begin{array}{ll}1.2 .1 \text { Fields; Chance } & 24\end{array}$

1.2.2 Burk \& Horton 25

$\begin{array}{ll}1.2 .3 \text { Underwood } & 26\end{array}$

$\begin{array}{ll}1.2 .4 \text { Best } & 26\end{array}$

$\begin{array}{ll}1.2 .5 \text { Cousins } & 26\end{array}$

$\begin{array}{ll}1.2 .6 \text { Posch } & 26\end{array}$

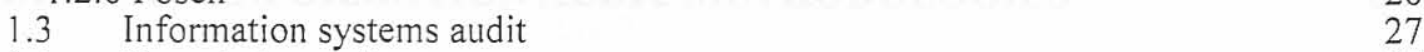

\begin{tabular}{ll}
1.4 & Knowledge audit \\
\hline
\end{tabular}

$\begin{array}{lll}1.5 & \text { Intelligence audit } & 28\end{array}$

2. The different types of audits: Methodologies 28

2.1 Communication audit 28

2.1.1 Cortez \& Bunge $\quad 29$

$\begin{array}{ll}2.1 .2 \text { Downs } & 30\end{array}$

2.1.3 Ferguson \& Ferguson $\quad 31$

2.2 Information mapping 33 
2.2.2 Burk \& Horton 34

$\begin{array}{ll}2.2 .3 \text { Underwood } & 37\end{array}$

$\begin{array}{ll}2.2 .4 \text { Best } & 39\end{array}$

$\begin{array}{ll}2.2 .5 \text { Cousins } & 40\end{array}$

\begin{tabular}{ll}
2.2 .6 Posch & 40 \\
\hline
\end{tabular}

2.3 Information systems audit 43

2.4 Knowledge audit 45

$\begin{array}{ll}2.5 & \text { Intelligence audit } \\ \end{array}$

3. Conclusion 45

CHAPTER 4: THE INFORMATION AUDIT - AN OVERVIEW 46

Chapter 4: Overview 46

1. Introduction 46

2. Definition: Information audit 46

2.1 "What an information audit is not" 49

2.2 Working definition: Information audit 50

3. The aim of an information audit $\quad 50$

4. Benefits of an information audit $\quad 52$

4.1 Benefits according to Downs 52

4.1.1 Validity benefit $\quad 52$

$\begin{array}{ll}\text { 4.1.2 Diagnostic benefit } & 54\end{array}$

4.1.3 Feedback benefit $\quad 54$

4.1.4 Information benefit $\quad 55$

$\begin{array}{ll}\text { 4.1.5 Training benefit } & 55\end{array}$

4.2 Benefits according to Underwood 56

4.3 Specific benefits: Case studies $\quad 56$

5. The value of information $\quad \mathbf{5 7}$

$\begin{array}{lll}5.1 & \text { Information as a resource } & 57\end{array}$

5.2 Determining the value of information 57

6. The role of the information audit in the information management process $\quad 58$

6.1 Definition: Information management 59

6.2 The need for information management: Typical information problems 60

6.3 Information auditing and information management 61

$\begin{array}{ll}\text { 6.3.1 The functions of information management } & 61\end{array}$

6.3.2 Different perspectives from the literature 64

6.3.3 The role of the information audit in the information management process: A
practical example

$\begin{array}{ll}\text { 7. Conclusion } & 67\end{array}$

CHAPTER 5: INFORMATION AUDIT METHODOLOGIES 68

$\begin{array}{ll}\text { Chapter 5: Overview } & 68\end{array}$

$\begin{array}{ll}\text { 1. Introduction } & 68\end{array}$

2. Different approaches to information auditing 68

2.1 Cost-benefit methodologies 68

$\begin{array}{lll}2.2 & \text { Geographical methodologies } & 68\end{array}$

$\begin{array}{ll}2.3 & \text { Hybrid methodologies } \\ \end{array}$

2.4 Management information methodologies 69 
2.5 Operational advisory methodologies $\quad 69$

2.6 Compliance, advisory and inventory-oriented audits 69

3. Methodologies $\quad 69$

$\begin{array}{lll}3.1 & \text { Barker } & 70\end{array}$

3.2 Hamilton 71

$\begin{array}{lll}3.3 & \text { Alderson } & 75\end{array}$

3.4 De Vaal \& Du Toit 76

$\begin{array}{lll}3.5 & \text { Dubois } & 77\end{array}$

3.6 Eddison $\quad 80$

3.7 Gibson 81

3.8 Jurek 82

3.9 LaRosa 84

3.10 Lubbe \& Boon 85

$\begin{array}{lll}3.11 & \text { Quinn } & 87\end{array}$

3.12 Riley 89

3.13 Robertson 89

3.14 St Clair 90

3.15 Stanat 93

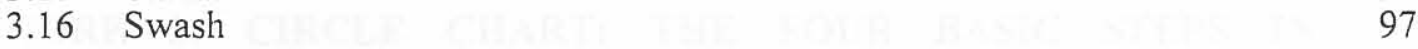

3.17 Webb 101

3.18 Worlock 103

3.19 Booth \& Haines 105

$\begin{array}{lll}3.20 & \text { Orna } & 107\end{array}$

3.21 Haynes 110

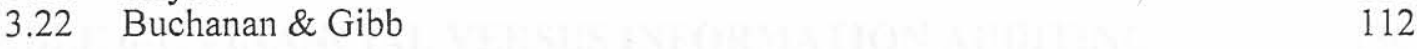

4. Other information audit applications $\quad 114$

4.1 O'Flaherty: Information user audit 114

4.2 EARL: Information needs assessment 115

4.3 Lewington: Information needs assessment 116

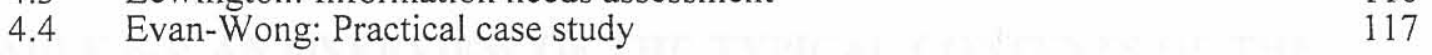

5. Comparison of different information audit methodologies 118

$\begin{array}{ll}5.1 & 119\end{array}$

$\begin{array}{lll}5.2 & \text { Geographical audits } & 122\end{array}$

$\begin{array}{ll}5.3 \text { Cost-benefit approach } & 123\end{array}$

5.4 Hybrid approach 124

$\begin{array}{ll}\text { 5.4.1 Operational advisory approach and geographical approach } & 124\end{array}$

$\begin{array}{lll}\text { 5.4.2 Operational advisory approach and cost-benefit approach } & 125\end{array}$

CHAPTER 6: CONCLUSION 128

$\begin{array}{ll}\text { Chapter 6: Overview } & 128\end{array}$

$\begin{array}{ll}\text { 1. Introduction } & 128\end{array}$

2. The information audit $\quad 128$

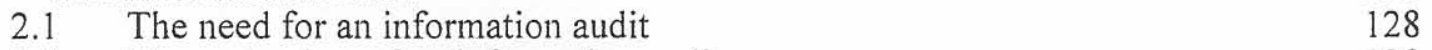

$\begin{array}{ll}2.2 & \text { The main aims of an information audit } \\ 2.3 & 128\end{array}$

$\begin{array}{ll}2.3 & \text { Lack of standardisation } \\ 2.429\end{array}$

$\begin{array}{ll}2.4 & \text { A standardised information audit methodology } \\ \end{array}$

3. Financial auditing versus information auditing 130

4. Guidelines for information auditing 136

$\begin{array}{ll}\text { 5. The future of information auditing } & 137\end{array}$

$\begin{array}{ll}\text { BIBLIOGRAPHY } & 140\end{array}$ 


\section{LIST OF FIGURES, TABLES AND ADDENDUMS}

TABLE 2-1: TYPICAL RESPONSIBILITIES OF AUDITORS

TABLE 2-2: OVERALL APPROACH TO AN OPERATIONAL AUDIT

TABLE 2-3: "METHODOLOGY" FOR A "TYPICAL" COMPLIANCE AUDIT

FIGURE 1 : SCHEMATIC OF COMMUNICATION AUDIT

FIGURE 2: HORN'S METHOD OF INFORMATION MAPPING

FIGURE 3: CIRCLE CHART: THE FOUR BASIC STEPS IN INVENTING OPTIONS

TABLE 5-1: INTERNAL VS. EXTERNAL INFORMATION SOURCES 100

TABLE 6-1: FINANCIAL VERSUS INFORMATION AUDITING

TABLE 6-2: WHAT INFORMATION PROFESSIONALS CAN LEARN FROM FINANCIAL AUDITS

TABLE 6-3: AN OVERVIEW OF THE TYPICAL CONTENTS OF THE ACTIVE WORKING PAPERS OF AN AUDITOR

ADDENDUM A: THE SOUTH AFRICAN INSTITUTE OF CHARTERED ACCOUNTANTS STATEMENTS ON AUDITING STANDARDS

ADDENDUM B: ASSURING THE QUALITY OF AUDIT AND RELATED SERVICES

ADDENDUM C: EXAMPLE OF A USER MATRIX

ADDENDUM D: EXAMPLE OF AN INFOMAP

ADDENDUM E: QUESTIONNAIRE

ADDENDUM F: INTERVIEW QUESTIONS

ADDENDUM G: BASIC ELEMENTS OF A SAMPLE QUESTIONNAIRE 154 


\section{ACKNOWLEDGEMENTS}

I would like to extend my gratitude towards the following persons and institutions:

- My study leader, prof. J.A. Boon, for his contribution towards this research.

- The NRF for the bursary that was awarded to me. The financial assistance enabled me to conduct this research.

- My family: my father, mother and two sisters for their invaluable emotional support. 


\title{
SUMMARY
}

\section{The information audit : principles and guidelines}

\author{
by
}

\author{
Hannerí Botha
}

\author{
Study leader: Prof. J.A. Boon \\ Department of Information Science \\ M.Bibl.
}

\begin{abstract}
Auditing is a recognised management technique. It provides managers with an overview of the present situation regarding specific resource(s) and services within an organisation.
\end{abstract}

Many different types of audits currently exist in the commercial world. Over the last number of years the focus of audits has shifted from a purely financial one to an interest in all activities performed in organisations, including information resources.

Currently, as far as the researcher could determine, there exists no single accepted methodology for performing an information audit. Methodologies differ from organisation to organisation, depending on the purpose of the specific audit. In view of this the researcher investigates whether it is possible (and desirable) to develop a standardised methodology for information auditing, by investigating the nature and characteristics of a typical information audit as well as a number of other audit types, e.g. the financial audit which is a very good example of a standardised audit methodology. Furthermore, the researcher discusses a number of terms and processes that have some connection to the process of information auditing, to a lesser or greater extent. These types of audits and processes are discussed with a view to indicating their applicability to designing an information audit methodology.

These include the communication audit because of its focus on organisational information flow patterns; Information mapping because of its focus on the identification and use of information resources; the information systems audit for its focus on the way in which technological tools are used to manage information resources (although implicitly); the knowledge audit follows logically on information management and information auditing (cf. explanation at the beginning of Chapter 3); and the intelligence audit for its relationship with both information and knowledge management.. The researcher concludes that none of these are the same as the information audit, though similarities exist.

The information audit is discussed by focusing on its aims, the benefits derived from performing an information audit and the role of the information audit in the information management process. Various information audit methodologies are discussed, evaluated and classified.

The researcher comes to the conclusion that even though the principles of the financial audit cannot be used to develop a standardised methodology for information auditing, information professionals can look towards the accounting profession to support them in developing a standardised, universally accepted method for accurately determining the value of information entities.

In conclusion, guidelines for a standardised information audit methodology are listed. 


\section{KEY TERMS}

- Audit

- Auditor

- Communication audit

- Information audit

- Information management

- Information mapping

- Information resource

- Information systems audit

- Intelligence audit

- Knowledge audit 


\title{
SAMEVATTING
}

\author{
Die inligtingsoudit: beginsels en riglyne
}

\author{
deur
}

Hannerí Botha

\author{
Studieleier: Prof. J.A. Boon \\ Departement Inligtingkunde \\ M.Bibl.
}

Ouditering is 'n erkende bestuurstegniek. Dit voorsien bestuurders van 'n oorsig van die huidige situasie met betrekking tot spesifieke hulpbron(ne) en dienste binne 'n organisasie.

In die kommersiële omgewing word verskillende tipes oudits gebruik. Met die verloop van tyd en veral oor die afgelope paar jare, het die fokus van oudits verander van 'n suiwer finansiële fokus na 'n fokus wat 'n verskeidenheid organisatoriese aktiwiteite en/of hulpbronne insluit, waaronder inligtingshulpbronne.

Die navorser het bepaal dat daar huidiglik nie 'n enkele, algemeen-aanvaarde metodologie bestaan vir die uitvoer van 'n inligtingsoudit nie. Bestaande metodologieë verskil van organisasie tot organisasie, afhangende van die doel van die spesifieke oudit. In die lig hiervan ondersoek die navorser of dit moontlik (en wenslik) is om ' $n$ gestandaardiseerde inligtingsoudit metodologie te ontwikkel. Die navorsing fokus onder andere op die aard en eienskappe van die tipiese inligtingsoudit, asook dié van 'n aantal ander tipes oudits, bv. die finansiële oudit - as 'n baie goeie voorbeeld van 'n gestandaardiseerde oudit metodologie. Die navorser bespreek ook 'n aantal terme en prosesse wat in 'n mindere of meerdere mate ooreenkoms(te) toon met die inligtingsoudit. Die doel van hierdie deel van die navorsing, is om aan te dui of/in watter mate hierdie prosesse gebruik kan word tydens die ontwerp van 'n inligtingsoudit metodologie.

Die oudits wat bespreek word, sluit in die kommunikasie oudit, aangesien laasgenoemde fokus op organisatoriese patrone van inligtingsvloei; "information mapping" aangesien dit fokus op die identifisering en optimale benutting van inligtingshulpbronne; die inligtingstelseloudit wat fokus op die tegnologiese hulpmiddels wat gebruik word tydens die (implisiete) bestuur van inligtingshulpbronne; die kennis oudit ontwikkel logies vanuit die prosesse van inligtingbestuur en inligtingsouditering (vgl. die bespreking aan die begin van Hoofstuk 3); en die intelligensie oudit wat 'n verwantskap toon met beide inligting- en kennisbestuur. Die navorser kom tot die gevolgtrekking dat geen van hierdie tipes oudits dieselfde is as die inligtingsoudit nie, maar dat ooreenkomste wel bestaan.

Die inligtingsoudit word bespreek deur te konsentreer op die doelwitte daarvan, die voordele wat dit inhou, en die rol van die inligtingsoudit in die inligtingbestuursproses. Verskeie inligtingsoudit metodologieë word krities bespreek, geëvalueer en geklassifiseer.

Die navorser kom tot die gevolgtrekking dat die beginsels van die finansiële oudit nie gebruik kan word om 'n gestandaardiseerde inligtingsoudit metodologie te ontwikkel nie. Ten spyte hiervan kan inligtingspesialiste baie leer van die rekenkundige beroep, veral wanneer daar gekyk word na die ontwikkeling van ' $n$ gestandaardiseerde, universeel-aanvaarde metode vir die akkurate berekening van die waarde van inligtingsentiteite. 
As gevolgtrekking tot die navorsing, word riglyne uiteengesit vir 'n gestandaardiseerde inligtingsoudit metodologie.

\section{SLEUTELTERME}

- "Information mapping"

- Inligtingbestuur

- Inligtingshulpbron

- Inligtingsoudit

- Inligtingstelsel oudit

- Intelligensie oudit

- Kennis oudit

- Kommunikasie oudit

- Oudit

- Ouditeur 